International Research Journal of Management, IT \& Social Sciences
Available online at https://sloap.org/journals/index.php/irjmis/
Vol. 5 No. 6, November 2018, pages: $80 \sim 92$
ISSN: 2395-7492
https://doi.org/10.21744/irjmis.v5n6.378

\title{
Influencing Factor on Brand Switching Behaviour between Millennial and X Generation in Mobile Phone Market
}

\begin{abstract}
CrossMark
Putu Dyah Permatha Korry ${ }^{a}$

Ni Wayan Suartini ${ }^{\text {b }}$
\end{abstract}

\section{Article history:}

Received: 5 July 2018

Accepted: 30 September 2018

Published: 15 November 2018

\section{Keywords:}

Brand switching;

Lifestyle;

Millennial generation;

$X$ generation;

Younger colleagues;

\begin{abstract}
Every generation owns the particular uniqueness in expectation, experience, generational history, lifestyle, value, and demography which influenced the buying behaviour. In terms of brand loyalty, $\mathrm{X}$ generation is less interested to try a new brand rather than their younger colleagues. Therefore, many companies reach their multi-generation customers and try to understand in order to get the attention of its various customers. Besides, consumer behaviour is the main field and resource of CRM (Customer Relationship Management) Program, therefore, it is important to evaluate the pattern and motive behind the buying behavior each generation through its own characteristics. This research aimed at knowing the influence of product quality, price, image brand, and electronic word of mouth (eWOM) to brand switching smartphone for $\mathrm{X}$ and Millennial generation. The sample of this research is 100 respondents of $\mathrm{X}$ generation and 100 respondents of Millennial Generation whom domiciliated in Denpasar City. The techniques of collecting the sample are purposive sampling method. The method of analyzing data by using Multiple Linear Regression by testing $\mathrm{R}^{2}$, $\mathrm{t}$-test, $\mathrm{f}$ test, and ANOVA test. By doing a hypothesis test, product quality and price have a significant positive impact to brand switch in X generation while in the Millennial generation, the factor which has a significant positive impact is the brand image. The result of t-test shows that variable of product quality, price, brand image, and whom has simultaneously impact to brand switching for both generations. The result for $\mathrm{R}^{2}$ test of $\mathrm{X}$ generation is $55 \%$ and Millennial generation is $11 \%$. The result of the ANOVA test shows that there is average diversity in both generations with 0,005 significance.
\end{abstract}

2395-7492@ Copyright 2018. The Author. This is an open-access article under the CC BY-SA license (https://creativecommons.org/licenses/by-sa/4.0/) All rights reserved.

\section{Author correspondence:}

Putu Dyah Permatha Korry,

Faculty of Economic and Bussiness Universitas Pendidikan Nasional (Undiknas), Denpasar, Indonesia

Ph: +6281 79702369

Email address: mithakorry@gmail.com

\footnotetext{
a Universitas Pendidikan Nasional (Undiknas), Denpasar, Indonesia

${ }^{\mathrm{b}}$ Universitas Mahendradatta, Denpasar, Indonesia
} 


\section{Introduction}

The brand is the most worthed assets for any companies and has widely known as the main reason for Consumer choice. It is functioned as the consumer device to check on the differentiation product and its uniqueness to enrich the consumer confidence in facilitating their decision-making process. According to American Marketing Association (AMA) in Kevin Lane Keller (2013) book defined that brand as a name, term, sign, symbol, or design or the whole combination in order to identify the things or service of a particular seller or seller group and to distinguish the product or service of the opposition. Thus, a brand can be several problems related to the experience and quality of the consumer confidence to the product.

Significant alteration in the whole population globally which requires the managers to develop the comprehension in this particular Adetunji et al., (2017), segment to be able to extend the effective marketing communication. As we know that, the development in information technology has brought business to distinguish level and give impact to the consumer behaviour. There are many marketers believe that variable of consumer behavior which is related to a case, advantage, user status, usage level, the readiness stage of the buyer, loyalty status and acts is the best starting point to fabricate the market segment.

According to the research of Jackson et al., (2011), social macro level, politics and economic case for years make the characteristics diversity in every generation, then the demography experts called this generational group as a cohort (group), a cohort. The generational group that is known from Baby Boomers for them who born from 1946 to 1964, X generation for them who born from 1965 to 1980, while Millennial Generation from 1981 to 2000. Every generation owns the particular characteristics. But the same thing is "They like buying" (Ordun, 2015). Hence, the alteration in consumption expense better to be comprehended through generational approach.

The X generation-buyers are proud of their independence and awareness since childhood. They have no purchasing power to use the product which is defined them in years of their growth. When they were young, $\mathrm{X}$ generation claimed as a rebel and disobeyed the tradition. This generation has no intention to other people mind and careless in using the product to show their status and similarity with others. In terms of Brand loyalty, they put on less interest to try a new brand compared to their younger and older colleagues. Otherwise, they chose to use the brand which they know and confident and willing to pay extra. A study was done by market research firm New York e-marketer expressed that four of ten consumers in this group stand for the brand they like.

The millennial generation has become the main addict to technology. For them, this innovation can give more than information resources and entertainment, and more than a new ecosystem to their social life. Ordun (2015) in his journal stated that from point of view of a pessimist, the millennial generation, they are claimed as lazy people, irresponsible, impatient, apathetic, egoist, disrespectful, and lost a generation. But, from the optimist point of view, they are labeled as open-minded people, social, innovative, energetic, ambitious, confident, motivated, and smart. Undergraduate students are millennial society, they become one of the highest contributors to increase the number of smartphone sales, the main users of social media and very expensive to the various product brands.

Based on this phenomenon, researchers demand to know the factors such as product quality, price, brand image, and eWOM can influence the decision of brand switching in mobile phone market according to the behaviour of each generation, even $\mathrm{X}$ generation and the millennial generation.

Korry, P. D. P., \& Suartini, N. W. (2018). Influencing factor on brand switching behaviour between millennial and $x$ generation in mobile phone market. International Research Journal of Management, IT and Social Sciences, 5(6), 80-92. https://doi.org/10.21744/irjmis.v5n6.378 


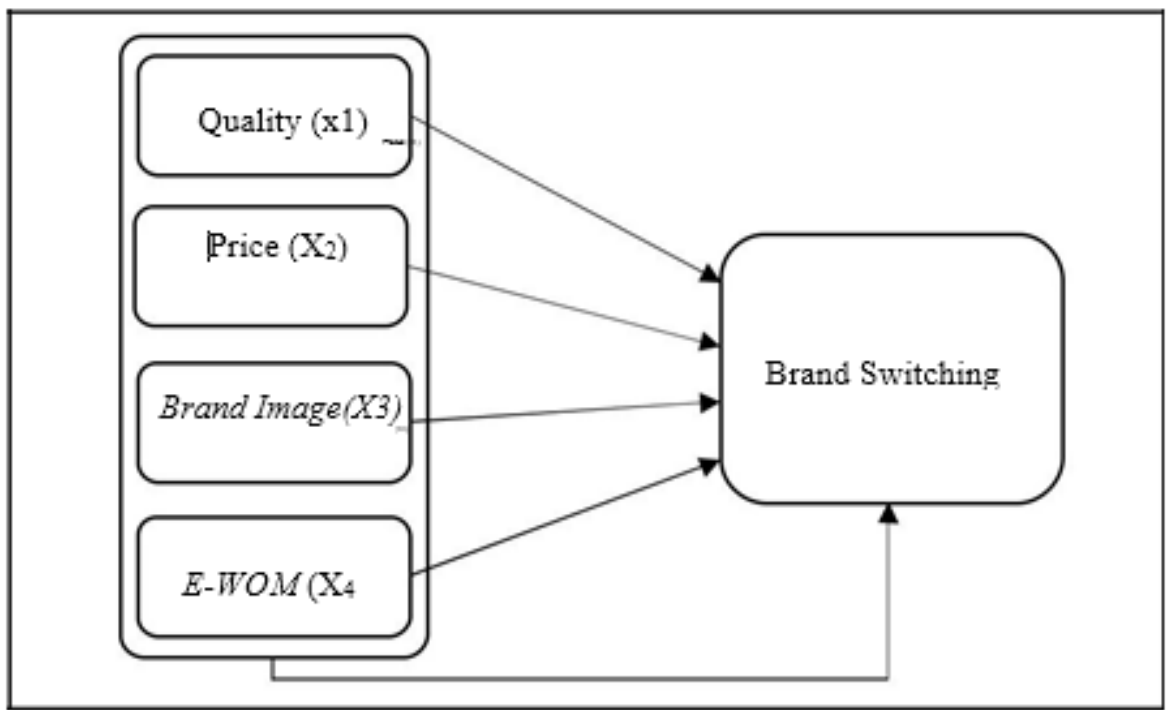

Figure 1. Critical framework

\section{Hypothesis}

H1 : Product Quality has a significant positive impact to brand switching in $\mathrm{x}$ generation

$\mathrm{H} 2$ : Price has a significant positive impact on the brand switching in $\mathrm{X}$ generation

$\mathrm{H} 3$ : Brand Image has a significant positive impact on Brand Switching in X generation

$\mathrm{H} 4$ : EWOM has a significant positive impact to brand switching in $\mathrm{X}$ generation

H5 : Product Quality has a significant positive impact to brand switching in the millennial generation

H6 : Price has a significant positive impact on brand switching in the millennial generation

H7 : Brand Image has a significant positive impact on Brand Switching in the millennial generation

H8 : EWOM has a significant positive impact to brand switching in the millennial generation

H9 : Product quality, price, brand image, and eWOM has simultant positive impact on Brand Switching in X

H10 : Product quality, price, brand image, and eWOM has simultant positive impact on Brand Switching in Millenial generation

H11 : The existence of significant diversity to Brand Switching X generation and Millennial generation.

\section{Literature review}

Kotler \& Amstrong (2008) stated that product quality is the characteristic of product and service which depend on its capability to satisfy consumer needs and be avowed or implied. It also becomes the main positioning facility in entering the market. Quality product, whether a thing or service need to be determined through its dimensions, claimed as a quality product or service dimensions.

Tjiptono (2008) divided eight dimensions of quality which can be an assessment of the product quality, as follows:

a) Performance is a characteristic of the main operation from the bought core product

b) Features are special additional characteristics to complete the basic function of a product

c) Reliability can be seen through the probability of failure or product damage

d) Conformance is the standard or status where a thing or service fulfills the standardization.

e) Conformance to specification is the way the design characteristics and product operation product operations meet predetermined standards.

f) Durability related to the length of time product can be used. This dimension covers the technical length time and economic time of product use. 
g) Service Ability, is speed of competence, comfort and convenience reparation and the ability of individual service in satisying the complain handling

h) Aesthetics is an attractiveness of a product to the five senses

Consumers can be very sensitive to the price, since that the price can be one of the factors that is most often noticed in advance to choose a product. According to Mowen \& Minnor (2006), a brand is bought because of the comfort, availability, or price. If one of the factors change, there was high probability consumer switching the brand. Commonly, companies adjust the basic price to calculate the difference between consumers and situation (Kotler \& Keller, 2008).

A Brand should have its own primacy to compete, it becomes a reason for the consumer to choose the brand. Brand uniqueness association can be based on the product attribute, its function, or image that could attract consumers. Kotler \& Amstrong (2006) stated that brand image influenced by several factors out of the company's control. The effective image can influence these three things as follows, first, to strengthen the characteristics and proposed product value. Second, to convince characteristics in a different way to avoid mistaken with the opposite. Third, to give emotional strength more than a mental image. To serve, the image should be given through means of communication and available contact of the brand.

Hasan (2010) defined word of mouth as consumer act in giving information to another person (interpersonal) about the brand or product. While Jansen et al., (2009), in his research explained that although it is similar to WOM in the outline, eWOM could give new alternatives to share the product anonymous and secretly, and also could across distance and region boundaries

Research by Henning Thurau et al., in Gunawan et al., (2016) reflected eWOM to be eight dimensions, as follows:

a) Platform Assistance, to operate the eWOM act through two ways, according to the frequency of consumer visits in opinion platform and number of comments written in opinion platform.

b) Venting Negative Feeling, this activity generally in eWOM negative when not satisfy consumer to a product shares their experience on the internet.

c) Concern for Other Consumers, sincere desire to help others to decide to buy a product.

d) Extraversion/Positives Self-Enhancement, the psychological motive of eWOM communicator give positive impact and also have demand for self-improvement.

e) Social Benefits, gain the attention in social media become a reason of eWOM communicator.

f) Economic Incentive, economic advantages has become one of human driving behavior and become one of the rewards for a human endeavor itself.

g) Helping the Company, the satisfaction of consumer who has been consumed a product continuously help the company to reference the product to another person.

h) Advice Seeking, in context of web opinion platform base, a reader who has read or seen the product reviewed by other, therefore the reader also interested to give a comment about the product. So, the chat can attract other readers, even though indirectly participate in reviewing the product.

Brand switching behavious is a complex phenomenon which can occur because to environmental influence, the existence of similar product offerings which is cheaper or because of the failure or problem of the bought product.

In the international journal of Economy and Management by Gunawan et al., (2016), the indicators of brand switching can be determined as follows:

a) Internal environment

This factor of Consumer appears in the consumer-self when considering the brand-selection, they thought that brand in their mind and brand that appear while the search for it. Brand preference is saved in consumer memory and appear after it stimulated. Furthermore, the unsatisfying experience of a previous product will drive the consumer to a pressure which will be evaluated through rational or cognitive assessment.

b) External environment

External environment as a factor outside the consumer-self which can influence the brand switching. It consists of promotion inside the shop and product unavailability. Shop promotion will give a reason to the consumer to do the brand switching. Furthermore, the unavailability of the product also caused brand switching. There is a possibility, when the consumer cannot find their favourite brand to evaluate another brand then buy it.

c) Emotional respond

Basically, emotional response is a response based on the effective component which see a process of changing attitudes of an individual when observing a thing according to the signal. This feeling immediately appears as the result of quick evaluation which relies on the confidence of a person. This emotional respond measure with

Korry, P. D. P., \& Suartini, N. W. (2018). Influencing factor on brand switching behaviour between millennial and $x$ generation in mobile phone market. International Research Journal of Management, IT and Social Sciences, 5(6), 80-92. https://doi.org/10.21744/irjmis.v5n6.378 
curiosity of the consumer. The other element of emotional response is the impulsive purchase caused by the surprise consumers' feelings that the unexpected products are available in their stores patronizing.

d) Rational respond

The rational response is a simultaneous consumer respond as a result of intellectual awareness of a person after getting interesting information and basic evaluation. The other dimension from this response is product evaluation, it is a consumer's behaviour when they learn about a product and compare the consumed one to the alternative product.

\section{Materials and Methods}

This research located in Denpasar City. Wherein the questionnaires are given to $\mathrm{X}$ generation respondents and Millennial Generation respondents who have been doing brand switching for mobile phone purchasing. The used technique of collecting data is by distributing the questionnaires to be answered by the respondents. The answers will be measured by using Likert Scale. Analyzing techniques used in this research is quantitative analysis by using multiple regression analysis tools. Linear regression is used to know the availability of impact among product quality, price, brand image, and electronic word of mouth to brand switching. The equation of multiple linear regression is:

$$
Y=a+b 1 X 1+b 2 X 2+b 3 X 3+b 4 X 4
$$

From the regression results obtained then examine to know the regression coefficient has a significant influence not, simultaneously or partially and to know the amount of the influence. Furthermore, one-way ANOVA test also is done in aimed at to know the existence of average diversity between two or more group sample.

\section{Results and Discussions}

\section{Finding Research}

A respondent from $\mathrm{X}$ generation as much as 102 persons or $47,4 \%$, while respondent from millennial generation is 113 persons or $52,6 \%$, the result of millennial generation respondent is more since the questionnaires are distributed via online so that easier to reach the millennial respondents which are bound to their smartphone. From the occupation point of view, the respondents are dominated by college students about 80 persons or 37,2\% as a millennial society, when smartphone become the necessity for them and its selection usually is affected by its group, it is the reason the chosen brand is depended on the popular trend among their society. The monthly income from all respondent is various, where the number of respondents and their income IDR. 3.000.000 about 68 persons with percentage $31,6 \%$ as the most choice

Validity Test

Table 1

Validity test result for questionnaires data

\begin{tabular}{lccc}
\hline Indicator & & & Note. \\
\hline Product Quality & & & \\
Indicator KP1 & 0.689 & 0,271 & Valid \\
Indicator KP2 & 0.521 & 0,271 & Valid \\
Indicator KP3 & 0.620 & 0,271 & Valid \\
Indicator KP4 & 0.661 & 0,271 & Valid \\
Indicator KP5 & 0.604 & 0,271 & Valid \\
Indicator KP6 & 0.644 & 0,271 & Valid \\
Indicator KP7 & 0.472 & 0,271 & Valid \\
Indicator KP8 & 0.751 & 0,271 & Valid \\
& & & \\
\hline
\end{tabular}




\begin{tabular}{|c|c|c|c|}
\hline \multicolumn{4}{|l|}{ Price } \\
\hline Indicator H1 & 0.451 & 0,271 & Valid \\
\hline Indicator $\mathrm{H} 2$ & 0.646 & 0,271 & Valid \\
\hline Indicator H3 & 0.554 & 0,271 & Valid \\
\hline \multicolumn{4}{|l|}{ Brand Image } \\
\hline Indicator BI1 & 0.578 & 0,271 & Valid \\
\hline Indicator BI2 & 0.763 & 0,271 & Valid \\
\hline Indicator BI3 & 0.558 & 0,271 & Valid \\
\hline \multicolumn{4}{|l|}{ eWOM } \\
\hline Indicator EW1 & 0.437 & 0,271 & Valid \\
\hline Indicator EW2 & 0.557 & 0,271 & Valid \\
\hline Indicator EW3 & 0.358 & 0,271 & Valid \\
\hline Indicator EW4 & 0.770 & 0,271 & Valid \\
\hline Indicator EW5 & 0.729 & 0,271 & Valid \\
\hline \multicolumn{4}{|l|}{ Brand Switching } \\
\hline Indicator BS1 & 0.660 & 0,271 & Valid \\
\hline Indicator BS2 & 0.703 & 0,271 & Valid \\
\hline Indicator BS3 & 0.524 & 0,271 & Valid \\
\hline Indicator BS4 & 0.509 & 0,271 & Valid \\
\hline Indicator BS5 & 0.597 & 0,271 & Valid \\
\hline Indicator BS6 & 0.601 & 0,271 & Valid \\
\hline
\end{tabular}

Source: Research 2017 (processed data)

Based on the table 1, the indicators used to measure the used variables in this research has correlation coefficient more than $r_{\text {table }}=0,271$ (value $r_{\text {table }}$ for $n=100$ ), that the indicators are valid.

\section{Reliability Test}

Table 2

Table of data reliability test result (questionnaire)

\begin{tabular}{lll}
\hline Variable & $\begin{array}{l}\text { Cronbach's } \\
\text { Alpha }\end{array}$ & Status \\
\hline Quality & 0.858 & Reliable \\
Product & 0.734 & Reliable \\
Price & 0.575 & Reliable \\
Brand Image & 0.787 & Reliable \\
$\begin{array}{l}\text { EWOM } \\
\text { Brand }\end{array}$ & 0.803 & Reliable \\
Switching & & \\
\hline \multicolumn{2}{l}{ Source: Research } \\
\end{tabular}

Source: Research 2017 (processed data)

This result shows that all of the variables have Cronbach Alpha in respectable amount 0,60, it can be concluded that for the next the items in each concept of the variable is proper to use as a measuring instrument.

Korry, P. D. P., \& Suartini, N. W. (2018). Influencing factor on brand switching behaviour between millennial and $x$ generation in mobile phone market. International Research Journal of Management, IT and Social Sciences, 5(6), 80-92. https://doi.org/10.21744/irjmis.v5n6.378 
The technique of Multiple Regression Analysis

1. X Generation

Tabel 3

Multiple regression result on $\mathrm{X}$ generation

\begin{tabular}{lllll}
\hline & Model & \multicolumn{2}{l}{ Unstandardized Coefficients } & $\begin{array}{l}\text { Standardized } \\
\text { Coefficients } \\
\text { Beta }\end{array}$ \\
\hline 1 & B Constant) & .674 & Std. Error & \\
& QP & .272 & .266 & .295 \\
& H & .298 & .098 & .358 \\
BI & .151 & .068 & .166 \\
& EW & .084 & .099 & .103 \\
\hline
\end{tabular}

Source: Research 2017 (processed data)

Based on table above, the equality of Multiple Linier Regression in this research is:

$$
Y=0.674+0.272 X 1+0.298 X 2+0.151 X 3+0.084 X 4
$$

The equality shows that quality product $\left(\mathrm{X}_{1}\right)$, price $\left(\mathrm{X}_{2}\right)$, brand image $\left(\mathrm{X}_{3}\right)$, and eWOM $\left(\mathrm{X}_{4}\right)$ able to affect the brand switching decision of a mobile phone to another brand on $\mathrm{X}$ generation. Product Quality and Price have positive coefficient regression which prove that its contribution to the up and down brand switching behaviour on X Generation.

\section{Determination Coefficient}

Table 4

Determination coefficient on $\mathrm{X}$ generation

\begin{tabular}{lllll} 
Model & $\mathrm{R}$ & $\begin{array}{l}\mathrm{R} \\
\text { Square }\end{array}$ & $\begin{array}{l}\text { Adjusted } \\
\text { R Square }\end{array}$ & $\begin{array}{l}\text { Std. Error of } \\
\text { The Estimate }\end{array}$ \\
\hline 1 & .742 & .551 & .532 & .503 \\
\hline \multicolumn{5}{r}{ Source: Research 2017 (processed data) }
\end{tabular}

Based on Table 4 is obtained the coefficient of determination about 0.551 . This shows that $55 \%$ of brand switching variable $(\mathrm{Y})$ can be explained by product quality $\left(\mathrm{X}_{1}\right)$ and price $\left(\mathrm{X}_{2}\right)$, brand image $\left(\mathrm{X}_{3}\right)$ and eWOM $\left(\mathrm{X}_{4}\right)$, while $45 \%$ is the influence of other independent variables that are unexplained by the research model, such as peer influence, developing trends, macroeconomic conditions, demographics, and technological developments.

T-Test

Table 5

$\mathrm{T}$ (partial) test result on $\mathrm{X}$ generation

\begin{tabular}{llll}
\hline & Model & T & Sig. \\
\hline 1 & (Constant) & 2.528 & .013 \\
& QP & 2.760 & .007 \\
& H & 4.363 & .000 \\
& BI & 1.523 & .131 \\
& EW & 1.173 & .244 \\
\hline
\end{tabular}

Source: Research 2017 (processed data) 
Based on Table 5 above is obtained as follows:

a) Value of $t_{\text {count }}$ for a quality variable Product (2.760) is bigger than value $t_{\text {table }}(1.665)$, or value Sig. T for product quality variable $(0.007)$ is smaller than alpha (0.05).

b) Value $t_{\text {count }}$ for price variable (4.363)

Bigger than value $t_{\text {table }}(1.665)$, or value Sig. $T$ for price variable $(0.000)$ is smaller than alpha $(0.05)$

c) Value $t_{\text {count }}$ for brand image variable

(1.523) is smaller than value $t_{\text {table }}(1.665)$ or value Sig. $t$ for brand image variable $(0.131)$ is bigger than alpha $(0.05)$

d) Value $t_{\text {count }}$ for variable eWOM (1.173) is more than the value of $t_{\text {table }}(1.665)$ or Sig. $t$ for eWOM variable (0.244) is bigger than alpha (0.05).

Based on the obtained result, $\mathrm{H} 1$ and $\mathrm{H} 2$ are accepted, while $\mathrm{H} 3$ and $\mathrm{H} 4$ are rejected. Therefore, partially, only product quality and price variables have positive impact significantly and another variable i.e., brand image and eWOM has insignificant effect to brand switching of $\mathrm{X}$ generation consumers.

\section{Millennial Generation}

Table 6

Multiple regression result of millennial generation

\begin{tabular}{lllll}
\hline \multirow{2}{*}{ Model } & \multicolumn{2}{c}{ Unstandardized Coefficients } & $\begin{array}{l}\text { Standardized } \\
\text { Coefficients } \\
\text { Beta }\end{array}$ \\
\cline { 3 - 4 } & B & Std. Error & \\
\hline 1 & (Constant) & 1.930 & 1.027 & .094 \\
& QP & .186 & .212 & -.084 \\
H & -.153 & .191 & .312 \\
BI & .429 & .151 & -.035 \\
EW & -.076 & .215 & \\
\hline
\end{tabular}

Source: Research 2017 (processed data)

Based on the table, the equality of multiple linier regression in this research is:

$$
Y=1.930+0.186 X 1-0.153 X 2+0.429 X 3-0.076 X 4
$$

This equality shows that product quality $\left(\mathrm{X}_{1}\right)$ and Brand image $\left(\mathrm{X}_{2}\right)$ able to influence the brand switching decision in selecting mobile phone brand to other brands on Millennial Generation. Product quality and brand switching have a positive coefficient regression that proved its contribution to the status of brand switching on Millennial Generation. The obtained impact of product quality, price, brand image and eWOM indicate that the elements in the product and prices assumed could influence the brand switching decision on Millennial Generation while the elements of brand image and eWOM variables assumed is partially yet sufficient to become a consideration of the consumers in Millennial Generation to switch the brand.

F-Test

Table 7

F Test Result (simultaneously) on Millennial Generation

\begin{tabular}{lllllll}
\hline Model & $\begin{array}{l}\text { Sum of } \\
\text { Square }\end{array}$ & df & $\begin{array}{l}\text { Mean } \\
\text { Square }\end{array}$ & F & Sig. \\
\hline 1 & Regression & 28.837 & 4 & 7.209 & 28.536 & $0.000^{\mathrm{b}}$ \\
& Residual & 23.496 & 93 & 0.253 & & \\
& Total & 52.333 & 97 & & & \\
\hline
\end{tabular}

Source: Research 2017 (processed data)

Korry, P. D. P., \& Suartini, N. W. (2018). Influencing factor on brand switching behaviour between millennial and $x$ generation in mobile phone market. International Research Journal of Management, IT and Social Sciences, 5(6), 80-92. https://doi.org/10.21744/irjmis.v5n6.378 
Based on table 7 is obtained that value of $F_{\text {count }}(28.536)$ is bigger than value $F_{\text {table }}(2.447)$ and sig. $\alpha\left(0.000^{b}\right)$ is smaller than alpha 5\% (0.05). This indicates that the finding research accepts $\mathrm{H}$ and reject $\mathrm{H}_{0}$. Thus, simultaneously product quality, price, brand image, and eWOM has simultant effect significantly to brand switching on millennial generation.

\section{Determination coefficient}

Table 8

Table determination coefficient on millennial generation

\begin{tabular}{lllll}
\hline Model & $\mathrm{R}$ & $\begin{array}{l}\mathrm{R} \\
\text { Square }\end{array}$ & $\begin{array}{l}\text { Adjusted } \\
\mathrm{R} \text { Square }\end{array}$ & $\begin{array}{l}\text { Std. Error of } \\
\text { The Estimate }\end{array}$ \\
\hline 1 & .341 & .116 & .079 & .632 \\
\hline \multicolumn{5}{c}{ Source: (processed data) }
\end{tabular}

Value of determination coefficient $\left(\mathrm{R}^{2}\right)$ is used to measure the magnitude of independent variable impact, i.e. product quality $\left(\mathrm{X}_{1}\right)$ and price $\left(\mathrm{X}_{2}\right)$, brand image $\left(\mathrm{X}_{3}\right)$ and eWOM $\left(\mathrm{X}_{4}\right)$ to the dependent variable, brand switching $(\mathrm{Y})$. According to table 4.11 is obtained determination coefficient value 0.116 . this shows that $11 \%$ brand switching variable $(\mathrm{Y})$ can be explained by product quality $\left(\mathrm{X}_{1}\right)$ and price $\left(\mathrm{X}_{2}\right)$, brand image $\left(\mathrm{X}_{3}\right)$ and eWOM $\left(\mathrm{X}_{4}\right)$, while $89 \%$ is the effect of other independent variables which is unexplained by the research model, among others income level, macroeconomic situation, demography, and technology development.

T-test

Table 9

T-test result on millennial generation

\begin{tabular}{llll}
\hline & Model & $\mathrm{T}$ & Sig. \\
\hline 1 & (Constant) & 1.880 & .063 \\
& QP & .878 & .382 \\
& H & -.803 & .424 \\
& BI & 2.847 & .005 \\
& EW & -.352 & .726 \\
\hline \multicolumn{2}{r}{ Source: (processed data) }
\end{tabular}

Based on the table above obtain the result as follow:

1) Value $t_{\text {count }}$ for a quality variable

Is smaller than $t_{\text {table }}(1.665)$, or value of Sig. $t$ for product value $(0.382)$ is bigger than alpha $(0.05)$.

2) Value of $t_{\text {cound }}$ for price variable $(-0.803)$

Is smaller than value $t_{\text {table }}(1.665)$ or value $\mathrm{Sig}$. $t$ for product variable $(0.005)$ is smaller than alpha $(0.05)$

3) Value $t_{\text {count }}$ for brand image variable

(2.847) is bigger than value table (1.665), or Sig. $t$ for the variable product (0.005) is smaller than alpha (0.05).

4) Value $t_{\text {count }}$ eWOM variable (-0.352) is smaller than $t_{\text {table }}(1.665)$, or value Sig. $t$ for product variable $(0.726)$ is bigger than (0.05).

Based on the obtained result, $\mathrm{H} 1, \mathrm{H} 2$, and $\mathrm{H} 4$ are rejected. Therefore, partially quality product variable, price, and eWOM is significantly influenced to switch the brand for consumers of Millennial generation. The brand image variable has an impact to brand switching behaviour of Millennial Generation.

Annova Test

Annova Test is used to differentiate the brand switching behaviour between X generation and Millennial generation, it can be seen in this table: 
Table 10

Anova test result

\begin{tabular}{lcccc}
\hline & $\mathrm{N}$ & Mean & $\mathrm{F}$ & Sig. \\
\hline GEN. X & 100 & 3.6700 & 8.180 & 0.005 \\
GEN & & & & \\
MILLENNIAL & 100 & 3.4433 & & \\
TOTAL & 200 & 3.5567 & & \\
\hline
\end{tabular}

Source: Research 2017 (processed data)

In order to see the existence of diversity in two groups which are tested could be known from the significant value of $\mathrm{X}$ generation and the millennial generation. The characteristic is if the significance is smaller than 0.05 so it is significant.

The data of table 10 is ANOVA test result in X generation and millennial generation, the obtained significant value is 0.005 , smaller than 0.05 which mean significant. In other words, there is a significant difference to brand switching in $\mathrm{X}$ generation and millennial which is shown by Mean Value.

\section{Conclusion}

The result of data analysis is the existence of diversity in brand switching pattern in X cohort and Millennial cohort. The conclusion of the data analysis is as follows.

1) Brand switching in $X$ generation

The obtained result of this research for $\mathrm{X}$ generation shows that product quality and price have a positive impact in influencing brand switching. It means that the first and second hypothesis of this research is accepted while brand image and eWOM have not a significant impact in influencing brand switching. It means that the third and fourth hypothesis is rejected. It can be concluded that the $\mathrm{X}$ generation is very considerate toward quality and price in selecting a mobile phone. In order to try a new brand is comparing with their younger colleagues. So, in order to prevent loyalty that has been built before on X generation, all elements in Samsung smartphone starting from being attached to the product to human resources, especially the customer service that must be able to serve the generation $\mathrm{X}$ segment well.

2) Brand switching in Millennial Generation.

The research is done on millennial generation shows that from the fourth independent variables, the only brand image has a significant positive impact in influencing brand switching. It means the seventh hypothesis is accepted while the fifth, sixth and eighth are rejected. This is suitable for the journal of the National Chamber Foundation, where Millennial is more open with new experience and a new brand. Moreover, recently technology development make the flow of information is rapidly flowing through the internet, and with only a touch we can find out the information we need. That is the reason for the marketing division of Samsung smartphone should arrange the mean of communication to intertwine the strong relationship with Millennial and make them the high loyalty costumers.

According to conclusions above, appropriated with ANOVA test i.e. the average diversity to brand switching in both cohorts, where the price has the biggest impact in influencing the brand switching decision on $\mathrm{X}$ generation, while the brand image is more dominated in influencing brand switching decision on the Millennial generation.

Suggestion

By the finding research, product quality variable and price influence brand switching for $\mathrm{X}$ generation while in the Millennial generation, brand image has an impact to brand switching on the mobile phone market. As the followingup of several findings of the research, the researchers recommend to the company and retailer or marketer of the mobile phone to pay more attention in factors in which influence each generation as what mentioned in advance. Such as in X generation, the company should create a good quality product with appropriate price, so that consumers feel they are not making a futile sacrifice to buy a smartphone. While for the millennial generation, the producers could intertwine

Korry, P. D. P., \& Suartini, N. W. (2018). Influencing factor on brand switching behaviour between millennial and $x$ generation in mobile phone market. International Research Journal of Management, IT and Social Sciences, 5(6), 80-92. https://doi.org/10.21744/irjmis.v5n6.378 
the relationship with the costumes through social media and create an image that Samsung is a suitable product for them. It is not the only thing, the futher research should analyze more than two cohorts to know the bigger market. This could bring a better comprehension toward the customer's behaviour.

Conflict of interest statement and funding sources

The authors declared that they have no competing interest. The study was financed by personal funding.

Statement of authorship

The authors have a responsibility for the conception and design of the study. The authors have approved the final article.

\section{Acknowledgments}

Our deep and sincere gratitude were presented to God for having granted us the ability and the opportunity to complete this paper. We would also like to thanks our friends for their support, their patience, their contribution, and their valuable input, therefore, this article could be complete. We would also thank the editor in IJCU who has reviewed and approved this study to be published. 


\section{References}

Adetunji, A. T., Adetunji, A. V., Adeleke, E. O., \& Madubuike, S. C. (2017). Deregulation: The Effect of Market-led Approach to Nigerian Universities Management. International Journal of Social Sciences and Humanities, 1(1), 18.

Gunawan, A., Diana, B., Muchardie, B. G., \& Sitinjak, M. F. (2016). The effect of involvement and Electronic Word of Mouth (eWOM) on brand image and its impact on consumers brand switching of Mamypoko. International Journal of Economics and Management, 10(S1), 19-31.

Hasan, A. (2010). Marketing dari mulut ke mulut. Word of Mouth Marketing, Media Pressindo, Yogyakarta.

Henning-Thurau, T. (2004). Motive des lesens von kundenartikulationen im internet: theoretische und empirische analyse. In Konsumentenverhalten im Internet (pp. 171-193). Gabler Verlag.

Jackson, V., Stoel, L., \& Brantley, A. (2011). Mall attributes and shopping value: Differences by gender and generational cohort. Journal of retailing and consumer services, 18(1), 1-9.

Jansen, B. J., Zhang, M., Sobel, K., \& Chowdury, A. (2009). Twitter power: Tweets as electronic word of mouth. Journal of the American society for information science and technology, 60(11), 2169-2188.

Keller, K. (2013). Strategic brand management: Global edition. Pearson Higher Ed.

Keller, K. L., Parameswaran, M. G., \& Jacob, I. (2011). Strategic brand management: Building, measuring, and managing brand equity. Pearson Education India.

Kotler, P. (2005). Manajamen pemasaran, jilid 1 dan 2. Jakarta: PT. Indeks Kelompok Gramedia.

Kotler, P. Dan Keller, Kevin Lane. 2009. Manajemen Pemasaran.

Kotler, P., \& Armstrong, G. (2008). Prinsip-prinsip pemasaran(Vol. 1). Jilid.

Mowen, J. C., \& Minor, M. (2002). Perilaku konsumen. Jakarta: Erlangga, 90.

Ordun, G. (2015). Millennial (Gen Y) consumer behavior their shopping preferences and perceptual maps associated with brand loyalty. Canadian Social Science, 11(4), 40-55.

Tjiptono, F., Chandra, G., \& Adriana, D. (2008). Pemasaran strategik. Yogyakarta: Andi.

Korry, P. D. P., \& Suartini, N. W. (2018). Influencing factor on brand switching behaviour between millennial and $x$ generation in mobile phone market. International Research Journal of Management, IT and Social Sciences, 5(6), 80-92. https://doi.org/10.21744/irjmis.v5n6.378 


\section{Biography of Authors}

\begin{tabular}{|l|l|}
\hline & $\begin{array}{l}\text { Putu Dyah Permatha Korry SE., MM. was born in Denpasar, 5 March 1985. Her } \\
\text { class/rank is IIIB-Penata Muda Tk.I, the academic position is Asisten Ahli. She is a } \\
\text { lecturer in Universitas Pendidikan Nasional Denpasar at J1. Bedugul No 39 Denpasar. } \\
\text { She lives in Perumahan Gria Agave, Jl. Semila Sari Barat No A5, Pemecutan, } \\
\text { Email: mithakorry @ gmail.com } \\
\text { Ph: +628179702369 }\end{array}$ \\
\hline \hline
\end{tabular}

